\title{
Patient Satisfaction with HIV and AIDS Services in Mizan-Tepi University Teaching Hospital, Southwest Ethiopia
}

This article was published in the following Dove Press journal: HIVIAIDS - Research and Palliative Care

\author{
Tadesse Nigussie (D) \\ Temesgen Aferu $\mathbb{D D}^{2}$ \\ Yitagesu Mamo ${ }^{2}$ \\ Mulugeta Feyisa $\mathbb{D}^{3}$ \\ 'Department of Public Health, College of \\ Health Sciences, Mizan-Tepi University, \\ Mizan Aman, Ethiopia; ${ }^{2}$ Department of \\ Pharmacy, College of Health Sciences, \\ Mizan-Tepi University, Mizan Aman, \\ Ethiopia; ${ }^{3}$ Department of Midwifery, \\ College of Health Sciences, Selale \\ University, Fiche, Ethiopia
}

Correspondence: Tadesse Nigussie Department of Public Health, College of Health Sciences, Mizan-Tepi University,

Mizan Aman, Ethiopia

Tel +25I-9II-598- 639

Email tadessenigussie21@gmail.com
Background: The World Health Organization and UNAIDS estimated that 36.9 million people were living with HIV in 2017 globally. In the same year, 1.8 million people became newly infected with HIV and 940,000 people died of AIDS-related illnesses. This study aimed to assess patient satisfaction with HIV and AIDS services in Mizan-Tepi University Teaching Hospital (MTUTH), Southwest Ethiopia.

Methods: A cross-sectional study was conducted from December 01/2018 to January 31/ 2019 among 348 people living with HIV who were on highly active antiretroviral therapy (HAART). A systematic random sampling technique was applied to select the study participants. Face to face interview was employed using structured questionnaires. The questionnaire consisted of socio-demographic factors, clinical factors, and patient satisfaction indicators for HIV and AIDS services. Level of satisfaction was assessed based on 24 Likertscale items. Logistic regression analysis was carried out to identify the independent predictors of patient satisfaction with the services given.

Results: A total of 348 respondents completed the interview, of which $213(61.20 \%)$ were male. The mean age of the respondents was $35.67(\mathrm{SD}=8.40)$. The overall level of clients' satisfaction with HIV and AIDS services was 55.2\%. Educational status of secondary school and above [AOR 2.41, 95\% CI: 1.24-4.69], duration of advice above $10 \mathrm{~min}$ [AOR 1.74, 95\% CI: 1.09-2.79], $\mathrm{CD}_{4}$ count $>500$ [AOR 2.20, 95\% CI: 1.37-3.54], and duration of treatment of 2 years and above [AOR 1.93, 95\% CI: 1.07-3.49] were identified as factors significantly associated with client satisfaction.

Conclusion: Overall, 55.20\% of patients were satisfied with HIV and AIDS services given at the ART clinic of MTUTH. Educational status, $\mathrm{CD}_{4}$ count, duration of advice, and duration of treatment were found to be independent predictors of patient satisfaction with ART services. Increasing client satisfaction is important through patient counseling and care. Keywords: antiretroviral therapy services, client satisfaction, Mizan-Tepi University Teaching Hospital

\section{Background}

Worldwide, it was estimated that 36.9 million people were living with HIV in 2017. In the same year, 1.8 million people became newly infected with HIV and 940, 000 people died of AIDS (acquired immune deficiency syndrome)-related illnesses. More than 35 million people have died of AIDS-related illnesses since the start of the epidemic. ${ }^{1}$

Ethiopia is among the countries highly affected by HIV (human immunodeficiency virus). There were 610,335 people living with HIV and estimated 13,556 deaths and 12,397 new infections in the country in 2017. The HIV prevalence rate 
among adults in Ethiopia was estimated to be $0.9 \%$; the prevalence of this infection varied by region. ${ }^{2}$ The global impact of the HIV pandemic, especially in the resourcelimited setting, is intense. A number of countries are showing retarded economic development, decreased citizen's life expectancy, deteriorated child survival rates, and an increased number of orphans due to this infection. ${ }^{3}$

Patient satisfaction is an important indicator of the quality of health care given. Patient satisfaction often determines whether a client seeks advice and care and adheres to a prescribed treatment schedule. ${ }^{4}$ Literature identified different factors associated with patient satisfaction with ART services, including distance from health facilities, age of patents, ${ }^{5}$ marital status, occupation, income, information provision and guidance, privacy, access of toilets and interpersonal communication ${ }^{6}$ and being female, employed and perceiving a high number of nurses working at the treatment center. ${ }^{7}$ Satisfied patients are more likely to adhere to their treatment and advice given by healthcare providers. In addition to this, they will return for additional care, especially for those on long-term treatment like Anti-Retroviral Therapy (ART). ${ }^{8}$ On the other hand, unsatisfied clients may behave differently and are likely to experience serious consequences like failure to follow treatment regimens, which results in the development of opportunistic infections and drug resistance. They may also fail to go for follow-up care and spread negative information to discourage others from using a health service. ${ }^{9-12}$

Even though there is a governmental effort to increase ART services and the number of clients enrolled in chronic care is increasing, patient loss to follow-up and ensuring adherence to ART regimens remain major challenges of the ART program in Ethiopia, and little has been done to evaluate patient satisfaction. ${ }^{13,14}$ Therefore, it was found important to undertake this study to assist in the evaluation of ART services from the patients' perspective. Furthermore, this study identifies areas of concern and generates solutions for the identified problems. This study aimed to assess the satisfaction of people living with HIV/AIDS with services given at the ART clinic of Mizan Tepi University Teaching Hospital (MTUTH).

\section{Methods}

\section{Study Setting and Period}

The study was conducted at Mizan Tepi University Teaching Hospital (MTUTH) from December 01/2018 to January $31 / 2019$. The hospital is found in Mizan Aman
Town, $585 \mathrm{Km}$ Southwest of Addis Ababa, the capital of Ethiopia. It is serving a total of 2 million people from four zones, including Bench sheko, Kefa, Sheka, and Majang, as referral center and had a total of 110 beds. About 350 clients visit the hospital daily for different services on average. The facility had more than 300 staffs including physicians, pharmacists, laboratory technicians, nurses, administrative staff members and supportive staff. There were 1733 HIV-positive patients getting services at this hospital during the study period. The patients visited the hospital monthly or every 2 months based on their adherence level. They were getting the services free of charge. ${ }^{15}$

\section{Study Design}

A facility-based cross-sectional study was employed to assess clients' satisfaction with HIV and AIDS services at MTUTH's ART clinic.

\section{Populations}

All clients who were receiving ART services at MTUTH's ART clinic were the source population. All randomly selected clients who were receiving HIV and AIDS services and fulfilled the eligibility criteria were the study population.

\section{Eligibility Criteria}

Patients who had been on ART for at least 6 months and the age of 18 years or above were included in the study, while those with difficulty in speaking, having difficulties in hearing, and who were severely ill were excluded.

\section{Sample Size Determination and Sampling Techniques}

The sample size required for this study was calculated using a single population proportion formula. Taking a $70 \%$ prevalence of client satisfaction with antiretroviral treatment services from Hossana, ${ }^{16}$ a $95 \%$ confidence level $\left(Z_{\alpha / 2}\right)$ and expected margin of error $(d)$ of $5 \%(0.05)$, the sample size was calculated to be 323 . Considering a $10 \%$ allowance for the non-response rate, the final sample size became 356 .

Systematic random sampling was used to select the study participants. K (sampling interval) was determined by dividing the total population on ART for sample size, ie $1733 / 356=5$. An exit interview was made for every five patients. 


\section{Study Variables}

Dependent variable: Clients' satisfaction with ART services

Independent variables: age, sex, marital status, educational status, occupation, residence, distance from a health facility, duration of advice, $\mathrm{CD}_{4}$, count and duration of treatment.

\section{Data Collection Instruments and Technique}

Structured English version questionnaires were adapted from different studies. ${ }^{9,16-18}$ The questionnaires were translated to the local language (Amharic) and then back to English by independent translators to ensure its consistency. The Amharic version questionnaire was used to collect data. The questionnaires consisted of sociodemographic factors, clinical/facility-related factors, and patient satisfaction indicators for ART services. A 24 itembased 5-point Likert scale ranging from strongly disagree to strongly agree (1 to 5 points) was used to determine patient satisfaction on different satisfaction items. Negatively arranged questions were recorded in reverse before analysis. A one-day training was given to the data collectors on the interview tools and how to approach patients. The questionnaires were also pre-tested before the collection of entire data in Chena Hospital, which is $40 \mathrm{~km}$ from MTUTH. Eighteen randomly selected patients who received ART services from the clinic were interviewed. A reliability test was done for items used to measure satisfaction, giving a cronbach alpha of 0.72 .

\section{Data Processing and Analysis}

The data were entered into Epi-data manager version 4.0.2.101 and exported to SPSS version 23 for analysis. Descriptive statistics such as frequency, percentage, mean, and standard deviation (SD) were used to summarize patients' characteristics. Binary logistic regression analysis was performed to select candidate variables for multivariable logistic regression. Finally, multivariable logistic regression analysis was undertaken on variables with $\mathrm{p}<0.25$ in binary logistic regression to identify the factors associated with client satisfaction. The association was declared significant at $\mathrm{p}<0.05$, and odds ratio with its $95 \%$ confidence intervals.

\section{Operational Definition and Measurements}

Services: All services provided for clients in the teaching hospital including examination, treatment, admission, referral, information, education, and counseling tests.
Patients/clients: People who were living with HIV and visited the hospital for ART service.

Satisfaction: Assessed using 24 Likert-scale items. The negatively arranged questions were recorded in reverse before calculating the scores to classify cuts of points. The mean score was calculated and patients who had a score above mean score were taken as satisfied while mean and below scores were considered as not satisfied.

Duration of advice: It was measured by asking the approximate minute the patient spent with his/her physician.

CD4 count: Was made by revising the patient record.

Duration of treatment: was obtained from the patient by asking the number of years of treatment, including the duration in other health facilities, if he/she was transferred from other health facility.

\section{Results}

\section{Socio-Demographic Characteristics}

Of the total 356 patients selected for the study, 348 completed the interview, making a response rate of $97.70 \%$. The mean age of the respondents was $35.67(\mathrm{SD}=8.40)$. More than half of the respondents, $213(61.20 \%)$ were male and Orthodox Christianity in religion,184 (52.90\%). Regarding their marital status, $252(72.40 \%)$ participants were married. One hundred sixty $(46.00 \%)$ had primary education and $105(30.20 \%)$ were merchants. Concerning ethnic composition, 105 (44.30\%) of participants were Amhara. Three hundred five $(87.60 \%)$ participants were from the urban setting Table 1 .

\section{Facility and Patient Treatment-Related Characteristics}

Almost all of the respondents had received advice from health workers, $340(97.70 \%)$. The advice given for most clients was $10 \mathrm{~min}$ and above, $200(57.50 \%)$ and the majority of the clients traveled less than $40 \mathrm{~min}$ to reach the health facility, $268(77.00 \%)$. Nearly $83 \%$ of the patients were receiving the treatment for 2 years or more. Approximately $95 \%$ of the clients did not experience opportunistic infection, and TB was the most reported opportunistic infection, 11 $(0.61 \%)$. Two hundred sixteen $(62.10 \%)$ participants had a $\mathrm{CD}_{4}$ count of greater than five hundred (Table 2).

\section{Source of Information About HIVIAIDS and Its Treatments}

The major source of information on HIV/AIDS and its treatment for clients in the study setting was health workers, 98 
Table I Socio-Demographic Characteristics of Clients Who Were on ART at MTUTH ART Clinic, Mizan-Aman Town, South West Ethiopia, January 2019

\begin{tabular}{|c|c|c|c|}
\hline Variables & Categories & Frequency & Percent \\
\hline \multirow[t]{4}{*}{ Age } & $<30$ & 119 & 34.3 \\
\hline & $31-40$ & 149 & 42.8 \\
\hline & $41-50$ & 60 & 17.2 \\
\hline & $>51$ & 20 & 5.7 \\
\hline \multirow[t]{2}{*}{ Sex } & Male & 213 & 61.20 \\
\hline & Female & 135 & 38.80 \\
\hline \multirow[t]{3}{*}{ Religion } & Orthodox & 184 & 52.90 \\
\hline & Protestants & 88 & 25.30 \\
\hline & Muslim & 76 & 21.80 \\
\hline \multirow[t]{3}{*}{ Marital status } & Single & 55 & 15.80 \\
\hline & Married & 252 & 72.40 \\
\hline & Divorced/widowed & 41 & 11.80 \\
\hline \multirow[t]{4}{*}{ Ethnicity } & Bench & 54 & 15.50 \\
\hline & Amhara & 154 & 44.30 \\
\hline & Kaficho & 115 & 33.00 \\
\hline & Others* & 25 & 7.20 \\
\hline \multirow{4}{*}{$\begin{array}{l}\text { Educational } \\
\text { status }\end{array}$} & No education & 63 & 18.10 \\
\hline & Primary school & 160 & 46.00 \\
\hline & Secondary school & 100 & 28.70 \\
\hline & $\begin{array}{l}\text { Above secondary } \\
\text { school }\end{array}$ & 25 & 7.20 \\
\hline \multirow[t]{5}{*}{ Occupation } & $\begin{array}{l}\text { Government } \\
\text { employee }\end{array}$ & 67 & 19.30 \\
\hline & Farmer & 38 & 10.90 \\
\hline & Housewife & 90 & 25.90 \\
\hline & Daily laborer & 48 & 13.80 \\
\hline & Merchant & 105 & 30.20 \\
\hline \multirow[t]{2}{*}{ Residence } & Rural & 43 & 12.40 \\
\hline & Urban & 305 & 87.60 \\
\hline
\end{tabular}

Notes: *Oromo, Gurhaghe, Sheko, Majangir.

(28.20\%). Clients who got information from radio, television, family members, and both radio and television were 83 (23.9\%), 54 (15.5), 47 (13.5\%), and 73 (21\%), respectively.

\section{Satisfaction with ART Services}

The overall level of clients' satisfaction with ART services at Mizan Tepi University Teaching Hospital's ART clinic was $55.20 \%$. The Likert scale results revealed that the mean rating values ranged from $1.67( \pm 0.78)$ to 4.32 $( \pm 0.93)$ with an overall mean rating of 3.46. The advice given on how the patients can cope with their disease $(\mathrm{M}=4.32( \pm 0.93))$ was rated the highest, whereas ideas about issues that should be improved regarding the care
Table 2 Facility and Clinical Condition-Related Characteristics of Clients at MTUTH ART Clinic, Southwest Ethiopia, January 2019

\begin{tabular}{|c|c|c|c|}
\hline Variables & Category & Frequency & Percent \\
\hline \multirow[t]{2}{*}{ Advice } & Yes & 340 & 97.70 \\
\hline & No & 8 & 2.30 \\
\hline \multirow[t]{2}{*}{$\begin{array}{l}\text { Duration of advice } \\
\text { in minute }\end{array}$} & $\begin{array}{l}\text { Less than } 10 \\
\text { minutes }\end{array}$ & 144 & 41.40 \\
\hline & $\begin{array}{l}10 \text { minutes } \\
\text { and above }\end{array}$ & 200 & 57.50 \\
\hline \multirow[t]{2}{*}{$\begin{array}{l}\text { Distance in minute from } \\
\text { health facility }\end{array}$} & $\begin{array}{l}\text { Less than } 40 \\
\text { minutes }\end{array}$ & 268 & 77.00 \\
\hline & $\begin{array}{l}40 \text { minutes } \\
\text { and above }\end{array}$ & 80 & 23.00 \\
\hline \multirow[t]{2}{*}{ Duration of treatment } & $\begin{array}{l}\text { Less than } 2 \\
\text { years }\end{array}$ & 60 & 17.24 \\
\hline & $\begin{array}{l}2 \text { years and } \\
\text { above }\end{array}$ & 288 & 82.76 \\
\hline \multirow{2}{*}{$\begin{array}{l}\text { Presence of } \\
\text { opportunistic infection }\end{array}$} & Yes & 18 & 5.17 \\
\hline & No & 330 & 94.83 \\
\hline \multirow{4}{*}{$\begin{array}{l}\text { Types of opportunistic } \\
\text { infections }\end{array}$} & TB & II & 0.61 \\
\hline & Pneumonia & 2 & 0.11 \\
\hline & Candidiasis & 3 & 1.67 \\
\hline & Others & 2 & 0.11 \\
\hline \multirow[t]{2}{*}{ CD 4 count } & $>500 / \mathrm{mm}^{3}$ & 216 & 62.10 \\
\hline & $<500 / \mathrm{mm}^{3}$ & 132 & 37.9 \\
\hline
\end{tabular}

given to the patients in the clinic $(\mathrm{M}=1.67( \pm 0.78))$ were rated the lowest (Table 3).

\section{Factors Associated with Client Satisfaction}

Multivariable logistic regression analysis results indicated that four variables were associated with patient satisfaction with ART services. Patients who attended secondary school and above were 2.41 times more likely to be satisfied when compared to those who were not educated [AOR 2.41, 95\% CI: 1.24-4.69]. Patients who were on follow-up for 2 years and above were 1.93 times more likely to be satisfied compared to those on treatment for less than 2 years [AOR 1.93, 95\% CI: 1.07-3.49]. Similarly, patients who got advice for more than $10 \mathrm{~min}$ were 1.74 times more likely to be satisfied when compared with those who received advice of less than $10 \mathrm{~min}$ [AOR 1.74, 95\% CI: 1.09-2.79]. With regard to CD4 count, those patients who had a $\mathrm{CD}_{4}$ count of 500 and above 
Table 3 Level of Satisfaction and Grading of Care Services Rendered to PLWHA at MTUTH ART Clinic, Mizan-Aman Town, South West Ethiopia, January $2019(n=348)$

\begin{tabular}{|c|c|c|c|c|c|c|c|}
\hline Items & $\begin{array}{l}\text { Strongly Dis } \\
\text { Agree F (\%) }\end{array}$ & $\begin{array}{l}\text { Disagree } \\
\text { F (\%) }\end{array}$ & $\begin{array}{l}\text { Neutral } \\
\text { F (\%) }\end{array}$ & $\begin{array}{l}\text { Agree } \\
\text { F (\%) }\end{array}$ & $\begin{array}{l}\text { Strongly Dis } \\
\text { Agree F (\%) }\end{array}$ & Total & $\begin{array}{l}\text { Mean } \\
\text { (SD) }\end{array}$ \\
\hline I feel when I come to the clinic & $40(11.5)$ & $84(24.1)$ & $9(2.6)$ & $123(35.3)$ & $92(26.4)$ & 348 & 3.41 (1.39) \\
\hline $\begin{array}{l}\text { I see physicians in the clinic are concerned } \\
\text { for my family }\end{array}$ & $12(3.4)$ & $10(2.9)$ & $7(2.0)$ & $203(58.3)$ & I I 6 (33.3) & 348 & $4.15(0.87)$ \\
\hline $\begin{array}{l}\text { Clean explanation was given for why I am } \\
\text { having tests done }\end{array}$ & $9(2.6)$ & $15(4.3)$ & $0(0)$ & $176(50.6)$ & I 48 (42.5) & 348 & $4.26(0.87)$ \\
\hline $\begin{array}{l}\text { There are a need of improvement in my care } \\
\text { in the clinic }\end{array}$ & 152 (43.7) & 182 (52.3) & I (0.3) & $4(1.1)$ & $9(2.6)$ & 348 & $1.67(0.78)$ \\
\hline $\begin{array}{l}\text { I am told everything I want to know about } \\
\text { my ART drugs }\end{array}$ & $12(3.4)$ & $16(4.6)$ & I (0.3) & $183(52.6)$ & 136 (39.1) & 348 & $4.19(0.92)$ \\
\hline $\begin{array}{l}\text { During my consultation I am given little or } \\
\text { no medical explanation }\end{array}$ & 17 (4.9) & $18(5.2)$ & I (0.3) & I |4 (32.8) & 195 (56.2) & 345 & $3.34(1.14)$ \\
\hline $\begin{array}{l}\text { The person I see in the clinic really knows } \\
\text { what he/she is talking about }\end{array}$ & $8(2.3)$ & $10(2.9)$ & $7(2.0)$ & $206(59.2)$ & II (33.6) & 348 & $4.19(0.80)$ \\
\hline Visiting the clinic is not a stressful occasion & $61(17.6)$ & $90(25.9)$ & $7(2.0)$ & $123(35.3)$ & $66(19.0)$ & 347 & $3.12(1.44)$ \\
\hline $\begin{array}{l}\text { I am given good advice on how to cope with } \\
\text { HIV }\end{array}$ & II (3.2) & $14(4.0)$ & $3(0.9)$ & $146(42.0)$ & $174(50.0)$ & 348 & $4.32(0.93)$ \\
\hline $\begin{array}{l}\text { No matter how long you have to wait in the } \\
\text { clinic, it's worth it }\end{array}$ & $86(24.7)$ & $90(25.9)$ & II (3.2) & $93(26.7)$ & $68(19.5)$ & 348 & $2.92(1.5 I)$ \\
\hline $\begin{array}{l}\text { I am satisfied with the care I receive in the } \\
\text { clinic }\end{array}$ & $18(5.2)$ & $31(8.9)$ & $2(0.6)$ & $129(37.1)$ & $168(48.3)$ & 348 & $4.14(1.14)$ \\
\hline $\begin{array}{l}\text { It's easy to get an appointment if I need to } \\
\text { come back to the clinic }\end{array}$ & $32(9.2)$ & $22(6.3)$ & $2(0.6)$ & $166(47.7)$ & $126(36.2)$ & 348 & $3.95(1.20)$ \\
\hline $\begin{array}{l}\text { I am given as much time as I need for my } \\
\text { consultation }\end{array}$ & $32(9.2)$ & $18(5.2)$ & $0(0.0)$ & $120(34.5)$ & I78 (5I.I) & 384 & $4.13(1.24)$ \\
\hline $\begin{array}{l}\text { The person I see in the clinic does not } \\
\text { understand what it's like to have HIV }\end{array}$ & I47 (42.2) & $146(42)$ & $3(0.9)$ & $20(5.7)$ & $32(9.2)$ & 348 & $1.98(1.22)$ \\
\hline $\begin{array}{l}\text { I have no confidence in the person who is } \\
\text { treating me }\end{array}$ & I 32 (37.9) & I5I (43.4) & $8(2.3)$ & $28(8.0)$ & $29(8.3)$ & 348 & $2.05(1.22)$ \\
\hline $\begin{array}{l}\text { I am rarely asked which treatments I would } \\
\text { prefer }\end{array}$ & 40 (II.5) & 61 (17.5) & $23(6.6)$ & $124(35.6)$ & $100(28.7)$ & 348 & 3.53 (1.37) \\
\hline $\begin{array}{l}\text { If I had a problem, I would find it easy to get } \\
\text { advice over the phone }\end{array}$ & $14(4.0)$ & $16(4.6)$ & $3(0.9)$ & $160(46.0)$ & I 55 (44.5) & 348 & $4.22(0.98)$ \\
\hline $\begin{array}{l}\text { My feelings about my treatment are taken } \\
\text { into consideration }\end{array}$ & $21(6.0)$ & 45 (12.9) & 4 (I.I) & I 55 (44.5) & $123(35.3)$ & 348 & $3.90(1.19)$ \\
\hline $\begin{array}{l}\text { Prescriptions for new tablets are given } \\
\text { without any explanation }\end{array}$ & 149 (42.8) & $147(42.2)$ & $0(0.0)$ & $27(7.8)$ & $25(7.2)$ & 348 & $1.94(1.18)$ \\
\hline $\begin{array}{l}\text { I am usually told what the possible side } \\
\text { effects of the tablets could be }\end{array}$ & $16(4.6)$ & $23(6.6)$ & $3(0.9)$ & 149 (42.8) & I 57 (45.I) & 348 & 4.17 (1.05) \\
\hline $\begin{array}{l}\text { I am encouraged to contact the I have } \\
\text { a problem with my health condition }\end{array}$ & $10(2.9)$ & $12(3.4)$ & $16(4.6)$ & I 56 (44.8) & I 54 (44.3) & 348 & $4.24(0.91)$ \\
\hline $\begin{array}{l}\text { The care I receive in the clinic is just about } \\
\text { perfect }\end{array}$ & $12(3.4)$ & $87(25)$ & $38(10.9)$ & $126(36.3)$ & $84(24.1)$ & 347 & $3.53(1.20)$ \\
\hline $\begin{array}{l}\text { Physicians are too busy to spend enough } \\
\text { time with me }\end{array}$ & 163 (46.8) & I43 (4I.I) & $5(1.4)$ & $21(6.0)$ & $16(4.6)$ & 348 & I.8 (I.05) \\
\hline $\begin{array}{l}\text { It's hard to get an appointment if I need it } \\
\text { quickly }\end{array}$ & 45 (12.9) & 121 (34.8) & $66(19.0)$ & $79(22.7)$ & $37(10.6)$ & 348 & $2.83(1.22)$ \\
\hline Overall mean satisfaction & & & & & & & 3.46 \\
\hline
\end{tabular}

Abbreviation: $F(\%)$, frequency (percent). 
Table 4 Factors Associated with Patient Satisfaction in MTUTH ART Clinic, Mizan-Aman Town, South West Ethiopia, January 2019

\begin{tabular}{|c|c|c|c|c|c|}
\hline \multirow[t]{2}{*}{ Variables } & \multirow[t]{2}{*}{ Categories } & \multicolumn{2}{|c|}{ Satisfaction Status } & \multirow[t]{2}{*}{$\operatorname{COR}[95 \% \mathrm{Cl}]$} & \multirow[t]{2}{*}{ AOR $[95 \% \mathrm{Cl}]$} \\
\hline & & Satisfied & Not Satisfied & & \\
\hline Age group & $\begin{array}{l}\text { Less than or equal to } 35 \text { years } \\
\text { Above } 35\end{array}$ & $\begin{array}{l}102 \\
90\end{array}$ & $\begin{array}{l}81 \\
75\end{array}$ & $\begin{array}{l}1.05[0.68-1.60] \\
\mathrm{I}\end{array}$ & $\begin{array}{l}\mathrm{I} .09[0.69-1.74] \\
\mathrm{I}\end{array}$ \\
\hline Educational status & $\begin{array}{l}\text { No education } \\
\text { Primary school } \\
\text { Secondary school and above }\end{array}$ & $\begin{array}{l}92 \\
66 \\
39\end{array}$ & $\begin{array}{l}33 \\
94 \\
24\end{array}$ & $\begin{array}{l}\mathrm{I} \\
0.60[0.33-1.08] \\
2.38[1.26-4.48]\end{array}$ & $\begin{array}{l}\text { I } \\
0.64[0.36-1.17] \\
2.41[1.24-4.69]^{*}\end{array}$ \\
\hline Residence & $\begin{array}{l}\text { Urban } \\
\text { Rural }\end{array}$ & $\begin{array}{l}71 \\
21\end{array}$ & $\begin{array}{l}134 \\
22\end{array}$ & $\begin{array}{l}0.75[0.40-\mid .4 I] \\
\mathrm{I}\end{array}$ & $\begin{array}{l}0.96[0.47-1.95] \\
1\end{array}$ \\
\hline Duration of treatment & $\begin{array}{l}\text { Less than } 2 \text { years } \\
2 \text { years and above }\end{array}$ & $\begin{array}{l}28 \\
164\end{array}$ & $\begin{array}{l}41 \\
114\end{array}$ & $\begin{array}{l}\text { I } \\
2.09[1.22-3.57]\end{array}$ & $\begin{array}{l}\text { I } \\
1.93[1.07-3.49]^{*}\end{array}$ \\
\hline Duration of advice & $\begin{array}{l}\text { Less than } 10 \text { minute } \\
10 \text { minute and above }\end{array}$ & $\begin{array}{l}99 \\
91\end{array}$ & $\begin{array}{l}101 \\
53\end{array}$ & $\begin{array}{l}\mathrm{I} \\
1.75[1.13-2.71]\end{array}$ & I.74 [1.09-2.79]* \\
\hline CD 4 count & $\begin{array}{l}\text { Below } 500 \\
500 \text { and above }\end{array}$ & $\begin{array}{l}56 \\
136\end{array}$ & $\begin{array}{l}76 \\
80\end{array}$ & $\begin{array}{l}\text { I } \\
2.31[1.48-3.59]\end{array}$ & $\begin{array}{l}\text { I } \\
2.20[1.37-3.54]^{*}\end{array}$ \\
\hline
\end{tabular}

Note: $* P$-value less than 0.05 .

were 2.2 times more likely to be satisfied with the ART services provided compared to those with a CD4 count of less than 500 [AOR 2.20, 95\% CI: 1.37-3.54] Table 4.

\section{Discussion}

This study revealed that $55.20 \%$ of clients were satisfied with HIV and AIDS services given at MTUTH. This is higher when compared to a study conducted in Vietnam, which indicated that the overall client satisfaction with ART services was $42.90 \% .{ }^{19}$ This might be because of differences in sample size and ART clinic numbers between these two studies. The sample size of the study from Vietnam was 6930 HIV-positive clients and 28 ART clinic sites, while the current study considered 356 patients and 1 study setting. Patient satisfaction level from the current study was in line with the study conducted in India, where overall patient satisfaction was $61.3 \%{ }^{20}$ It was lower than the report of the study done in Midre-genet hospital Tigray, Northern Ethiopia, which showed patient satisfaction to be $75.2 \%{ }^{6}$ Hossana town, Southern Ethiopia $70.10 \%,{ }^{16}$ study conducted in Gonder Town Health Center, Northwest Ethiopia, 75.4\% ${ }^{5}$ and study from Bamenda Cameroon, $71.4 \%$ patients satisfied with HIV and AIDS services. ${ }^{7}$ Problems in the availability and quality of diagnostic facilities, infrastructure and shortage of trained human power might be a reason for lower satisfaction levels in this study.

This study revealed that patients who completed secondary school and above were 2.41 times more likely to be satisfied with ART services compared to clients with no education. This is in line with a study conducted in Hossana Town. ${ }^{16}$ A study conducted at Gondar University referral hospital in Northwest Ethiopia also showed that the educational status of respondents was associated with satisfaction of HIV and AIDS. ${ }^{21}$ This might be because respondents who had high levels of education may request and access information about HIV and its related services from the facility more than uneducated and therefore they might be satisfied with the given services.

Patients who had been advised for $10 \mathrm{~min}$ and above were 1.74 times more likely to be satisfied compared to those who were advised for less than $10 \mathrm{~min}$ in the current study. This is similar to a study from West Wollega, which showed a long duration of consultation/discussion was associated with a high satisfaction score. ${ }^{22}$ If the patient and physician discussed the disease and treatment, taking enough time to misconception and different issues would be clarified for the patient. A study conducted in the Tigrai region of Northern Ethiopia also suggested that patients who had interpersonal communication were more likely to be satisfied with HIV and AIDS services given. ${ }^{6}$ This might be due to the fact that patients understand the impact of the duration of advice on their health and hence interested in lengthy advice.

In this study, patients with a $\mathrm{CD}_{4}$ count greater than or equal to $500 / \mathrm{mm}^{3}$ were 2.20 times more likely to be satisfied than patients with a $\mathrm{CD}_{4}$ count of less than 500/ 
$\mathrm{mm}^{3}$. A recently conducted study in Vietnam also showed that a high level of satisfaction was correlated with good treatment outcomes explained by high CD4 count. ${ }^{23}$ This might be associated with the fact that CD4 count increases with ART follow up and patients' condition improves with increased CD4 count, which may result in positive patients' perception of the services rendered.

Treatment duration was found to be significantly associated with patient satisfaction in the current study. Patients with a treatment duration of 2 years and above were 1.93 times more likely to be satisfied with ART services compared to those who were on treatment for less than two years. The development of acquaintances by patients to the environment, treatment and health workers with increased treatment duration might be a reason for increased satisfaction.

\section{Limitations of the Study}

The study design was a cross-sectional study and therefore it does not show a causal relationship. Social desirability bias from the patients' side may also affect this study.

\section{Conclusion and Recommendations}

Of the interviewed patients, $55.20 \%$ of them were satisfied with the HIV and AIDS services given by MTUTH ART clinic. Still, it is low when compared to different studies conducted in different areas. Educational status, $\mathrm{CD}_{4}$ count, duration of advice, and duration of treatment were found to be independent predictors of patient satisfaction with ART services. Physician/health service providers should give attention especially to uneducated, new patients and have to assign sufficient time for advice. Zonal and Woreda health offices and Southern Nations, Nationalities and Peoples' Region Health Bureau and Ministry of Health should work in collaboration with other stakeholders to satisfy patients with items for which patients were not satisfied.

\section{Abbreviations}

AIDS, acquired immuno deficiency syndrome; ART, antiretro viral therapy; CD4, cluster of differentiation 4; CI, confidence interval; HIV, human immunodeficiency virus; UNAIDS, The Joint United Nations Programme on HIV/ AIDS; WHO, World Health Organization.

\section{Ethics Approval and Consent to Participate}

Ethical approval was obtained from the Mizan Tepi University College of Health Science Review Committee and permission was attained from MTUTH administration. The ethical committee also approved the procedure for written consent. This study was conducted in accordance with the Declaration of Helsinki. Also, all the fundamental ethical principles (including the respondents' written informed consent, risks, benefits and comfort of the respondents) were followed according to the research ethical guidelines. Each study participant provided written informed consent before joining the study.

\section{Funding}

No external fund was received for this work.

\section{Disclosure}

The authors report no conflicts of interest in this work.

\section{References}

1. UNSAID. Global HIV \& AIDS Statistics - 2018 Fact Sheet. Vol. 2017; 2018.

2. PEPFAR. Ethiopia Country Operational Plan (COP/ROP) 2018 Strategic Direction Summary; 2018.

3. UNSAID. Global AIDS Monitoring 2019; 2018.

4. Leon C, Koosed T, Philibert B, Raposo C, Benzaken AS. HIV/AIDS health services in Manaus, Brazil: patient perception of quality and its influence on adherence to antiretroviral treatment. BMC Health Serv Res. 2019;9:1-11.

5. Adissu G, Biks GA, Tamirat KS. Patient satisfaction with antiretroviral therapy services and associated factors at Gondar town health centers, Northwest Ethiopia: an institution-based cross-sectional study. BMC Health Serv Res. 2020;20(1):1-9. doi:10.1186/s12913020-4934-z

6. Atsebeha KG, Chercos DH. High antiretroviral therapy service delivery satisfaction and its " associated factors at Midre-genet hospital; Northwest Tigray. BMC Health Serv Res. 2018;18(223):1-9. doi:10.1186/s12913-017-2770-6

7. Wung BA, Peter NF, Atashili J. Clients ' satisfaction with HIV treatment services in Bamenda, Cameroon: a cross- sectional study. BMC Health Serv Res. 2016;6(280):1-9. doi:10.1186/s12913-0161512-5

8. Chimed-Ochir O. Patient satisfaction and service quality perception at district hospitals in Mongolia. Ritsumeikan J Asia Pac Stud. 2012;31.

9. Tateke T, Woldie M, Ololo S. Determinants of patient satisfaction with outpatient health services at public and private hospitals in Addis. AOSIS Open J. 2012;4(1):1-11. doi:10.4102/phcfm.v4i1.384

10. Length F. Clients ' satisfaction with anti retroviral therapy services in a tertiary hospital in Sokoto, Nigeria. J AIDS HIV Res. 2013;5 (9):328-333. doi:10.5897/JAHR2013.0247

11. Asefa A, Kassa A, Dessalegn M. Patient satisfaction with outpatient health services in Hawassa University Teaching Hospital, Southern. J Public Health Epidemiol. 2014;6:101-110. doi:10.5897/JPHE20 13.0613

12. de Jager GA, Crowley T, Esterhuizen TM. Patient satisfaction and treatment adherence of stable human immunodeficiency virus-positive patients in antiretroviral adherence clubs and clinics. Afr J Prim Health Care Fam Med. 2018;10(1):1-8. doi:10.4102/ phcfm.v10i1.1759

13. Aferu T Assessment of HIV/AIDS Services Quality in Health centers of East Shoa Zone, Oromia, Ethiopia; 2018. 
14. Republic FDR of E. Country Progress Report on the HIV; 2014.

15. MTUTH. Mizan Tepi University Teaching Hospital Annual Report; 2019.

16. Doyore F, Moges B. Client satisfaction to antiretroviral treatment services and associated factors among clients attending ART clinics in Hossana Town, Southern Ethiopia. Clin Res Trials. 2016;2(6). doi:10.15761/crt.1000160

17. Yakob B, Ncama BP. Client satisfaction: correlates and implications for improving HIV/AIDS treatment and care services in southern Ethiopia. Int Health. 2016;8(4):292-298. doi:10.1093/inthealth/ ihw008

18. Mindaye T, Taye B. Patients satisfaction with laboratory services at antiretroviral therapy clinics in public hospitals, Addis Ababa, Ethiopia. BMC Res Notes. 2012;5. doi:10.1186/17560500-5-184.

19. Tran BX, Nguyen NPT. Patient Satisfaction with HIV/AIDS Care and Treatment in the Decentralization of Services Delivery in Vietnam. PLoS One. 2012;7(10):e46680. doi:10.1371/journal. pone. 0046680
20. Dixit S, Verma N, Shrivastava N, Sharma M, Pradhan SK, Agarwal S. Patient satisfaction with ART centre services among people living with HIV: a cross sectional study in a tertiary care hospital, Chhattisgarh, India. Int J Community Med Public Health. 2018;5(6):2564. doi:10.18203/2394-6040.ijcmph20182195

21. Abebe TB, Erku DA, Gebresillassie BM, Haile KT, Mekuria AB. Expectation and satisfaction of HIV/AIDS patients toward the pharmaceutical care provided at Gondar university referral hospital, northwestern Ethiopia: a cross-sectional study. Patient Prefer Adherence. 2016;10:2073-2082. doi:10.2147/PPA.S114720

22. Habtamu A, Kifle Y, Ejigu Y. Client Satisfaction and its Determinants with Anti-Retroviral Therapy (ART) Services in Public Hospitals of West Wollega Zone, Ethiopia: a Cross Sectional Study. Galore Int J Appl Sci Humanit. 2017;1:1-16.

23. Tran BX, Dang AK, Vu GT, et al. Patient satisfaction with HIV services in Vietnam: status, service models and association with treatment outcome. PLoS One. 2019;14(11):1-13. doi:10.1371/journal.pone. 0223723

\section{Publish your work in this journal}

HIV/AIDS - Research and Palliative Care is an international, peerreviewed open-access journal focusing on advances in research in HIV, its clinical progression and management options including antiviral treatment, palliative care and public healthcare policies to control viral spread. The manuscript management system is completely online and includes a very quick and fair peer-review system, which is all easy to use. Visit http://www.dovepress.com/testimonials.php to read real quotes from published authors. 